\title{
THE RELATION BETWEEN HOME AND IDENTITY IN THE GIRL FROM THE GOLDEN HORN BY KURBAN SAID
}

\author{
Paramita Ayuningtyas \\ Jurusan Sastra Inggris, Fakultas Bahasa dan Budaya, Bina Nusantara University \\ Jln. Kemanggisan Ilir III No. 45, Palmerah, Jakarta Barat 11480
}

\begin{abstract}
The focus of this research entitled The Relation between Home and Identity in The Girl from The Golden Horn by Kurban Said is the relation of meaning of home and someone's perspective of identity. The research is conducted by analyzing the two main characters, Asiadeh and Abdul Kerim, and relating the conflicts they are facing to identity concept by Stuart Hall. Hall mentioned that identity is a process of becoming and also a matter of someone's position in the world. The discussion points out the identity crisis experienced by Asiadeh and Abdul Kerim when as Easterners, they have to live in Western world. It also shows that the characters finally succeeded in finding their home when they have taken their duty given by their their identity as the part of Ottoman Empire, which is to marry each other.
\end{abstract}

Keywords: cultural values, East-West relation, identity, Turkey

\begin{abstract}
ABSTRAK
Fokus dari penelitian berjudul The Relation between Home and Identity in The Girl from The Golden Horn by Kurban Said ini adalah kaitan makna rumah dan perspektif seseorang tentang identitas. Penelitian ini dilakukan dengan cara menganalisis dua tokoh utama, Asiadeh dan Abdul Kerim, dan mengaitkan konflik yang dihadapi oleh mereka dengan konsep identitas oleh Stuart Hall. Hall menyatakan bahwa identitas adalah sebuah proses menjadi dan juga masalah posisi seseorang di dunia. Hasil penelitian menunjukkan krisis identitas Asiadeh dan Abdul Kerim sebagai bangsa Timur yang harus tinggal di dunia Barat. Hasil analisis yang lain adalah kedua karakter tersebut pada akhirnya berhasil menemukan makna rumah ketika mereka melaksanakan tugas sesuai dengan identitas mereka sebagai bagian dari Kekaisaran Ottoman, yaitu dengan menikah.
\end{abstract}

Kata kunci: nilai budaya, hubungan Timur-Barat, identitas, Turki 


\section{INTRODUCTION}

Geographically, it can be said that Turkey is a unique country. It is located between two continents, Asia and Europe. The meeting of the two continents also leads to cultural confusion to the nation. The people are trapped between the two worlds, the East and the West. Many Turkish authors often bring up this topic in their works, and one of the finest examples is Orhan Pamuk with his novel My Name is Red (1998). Yet before Said, there is one Turkish author who already came up with the East-West clash issue, namely Kurban Said, with his novel The Girl from The Golden Horn (1938). The real identity of Kurban Said himself is not really clear since it is only a pseudonym.

Set in 1928, The Girl from The Golden Horn talks about the romance between Asiadeh, the protagonist, and an Austrian doctor named Hassa. Not only a love story, The Girl from The Golden Horn is also a novel about a searching for a lost home. Asiadeh comes from Turkey, and immediately after the fall of the Ottoman Empire, she and her pasha father have to flee to another country. Another character in the novel, prince Abdul Kerim, has to do the similar thing. Forced by the unstable situation, they must leave their home, the land of Turkey. In Cultural Studies, home is not plainly a place and has a significant meaning to one's identity: "It is social groups that make meanings and make places meaningful through social interactions."(Baldwin et.al, 2004: 143). Besides that, home is the place where a person is raised with particular cultural values. Related to the issue, how do Asiadeh and Abdul Karem face the fact that they have to leave behind their home? Then, in what ways will they find their home again? This research will find the answer to those questions by focusing on the two characters, including on their interaction to other people and to each other.

\section{METHODS}

The research will be conducted by reading thoroughly the novel The Girl from The Golden Horn and mainly analyzing the two characters, Asiadeh and Abdul Kerim. The concept of identity by Stuart Hall will be used to discuss the aforementioned issue in the introduction. According to Hall, identity is a flexible construction and a process of becoming, instead of being. This process of becoming happens endlessly, depending on various factors such as social and cultural condition, space and place (Rutherford, 1990). Identity also means how people position themselves and are positioned by other people. Therefore, identity is a matter of position, not essence. Regarding to the topic, the term 'identity crisis' appears. This crisis often happens when someone is trying to find his/her fixed position in the world. Identity is seen as a connecting bridge between an individual with the people around him/her. Using Cultural Study approach that focuses on identity, this research will discuss the identity problems experienced by Asiadeh and Abdul Kerim.

The methods are purposed: (1) to identify the identity problems faced by Asiadeh and Abdul Kerim. In this step, the researcher will analyze the internal conflict of each character and also the external conflict related to their interaction to other people; (2) to relate the conflicts with identity concept and its relation to the meaning of home. Here, it will be seen how the dilemmas both Asiadeh and Abdul Kerim feel are caused by their longing to a place called home. Whether they are experiencing identity crisis can also be discussed in this step; (3) to conclude from the analysis about how the meaning of home is significant to identity issues. 


\section{RESULTS AND DISCUSSIONS}

\section{Asiadeh and the Link to Home}

As a Turkish girl growing up in a harem, a part of a house set apart for women in the family, Asiadeh is experiencing a cultural shock when she moves to Germany. She no longer has to wear a veil and is free to wander along the streets by herself, the things that she cannot do when she was still in Turkey. She is enjoying the freedom although at the same time she is missing her home back in Turkey. To overcome the feeling, Asiadeh is studying Turking philology in university. To Asiadeh, by studying her ancestors' language, she could be connected to Turkish culture. "It's a link with home ..." (Said, 2001). Language is a significant element in determining someone's cultural identity. By studying Turkish language deeplier, Asiadeh feels that her identity as a Turkish will not disappear even though now she lives in a foreign country.

Besides that, to keep the feeling of being at home, Asiadeh always spares the time to be around other Turkish people or at least people from other Eastern countries (Eastern here does not only mean Asian countries; in Orientalists' point of view, other cultures outside Europe can be categorized as Eastern cultures), like Morocco or Egypt. She and her father are members of The Orient Club of Berlin, in which people forced to leave their Eastern home gather and share stories. The members of this club share the same fate, which is leaving their homeland then staying in the Western world: the place with totally different cultural values. It's not just the same experience that ties them together; they are united by their religion, Islam, as well: "There they were-people of all countries, unified by the word of the Koran" (p. 33). One important aspect of identity-finding process is the similarities with other people. When finally discovering them, someone might feel that he/she has a fixed identity or a position in the world. This phenomenon can be seen in Asiadeh. She always feels at home when she in The Orient Club of Berlin.

Cultural identity is not only a matter of a shared experience, but it also deals with material signs that remind someone of a certain culture. In The Orient Club of Berlin, the rooms are decorated with ornaments from the Eastern world such as carpets and rugs from the East. More than a decoration, these room ornaments are memories of the home that they have to leave. The club members' clothes also signify their origin, such as 'fezzes, turbans and white bedouin robes'. Here we can see how identity is performed by material conditions, which are decorations and clothes.

A small club in Berlin is a substitute of home for Asiadeh, a small Eastern world in the midst of the Western world. When Hassa, her lover, picks her up in front of the club, Asiadeh is feeling hesitant to leave the place:

She left the club and felt, even on the staircase, forsaken in a foreign hostile world. Behind her was home: eager servants, Negroes, princes, blood relations who would protect her honor, and pious dervishes who would remind her of sin. That was the world she knew, the world she could feel safe. (p. 37)

The quotation above shows how Asiadeh treats the club as her home, where she feels safe. 'Eager servants' and 'princes' are signs of an empire, and they remind Asiadeh of her previous life in Ottoman Empire. In the same quotation, the word 'Negroes' which refers to skin colour - which is often labeled as non-Western - can be found. In Giles and Middleton, Jefrey Weeks states that "identity is about belonging, about what you have in common with some people and what differentiates you from others" (1999, p. 50). With the club members, Asiadeh thinks that they share many things, and it strengthens her identity as an Easterner and differs her from the Westerners. 
When living in Western world, Asiadeh has to face the fact that it has different cultural values and its people have their own perspective in seeing the Eastern world. The Westerner's point of view is represented by Hassa's opinion about the East:

"The Orient," said Hassa contemptuously, "unhygienic housing and reactionary customs. It is losing more and more ground. In a hundred years' time, the Orient will be just a geographical term.” (p. 74)

As someone from the Western world, Hassa underestimates the Orient/the East by pointing out that it is a dirty place with strange traditions. He even predicts that in the future, the East will lose its grand reputation and will only serve as a geographical term. On the contrary with his husband, Asiadeh believes it is Turkey that is more civilized," And we did all we could to bring civilization to the country [Austria]. But the country refused to become civilized" (p. 90). The Easterner (represented by Asiadeh) and the Westerner (by Hassa) look at each other with negative opinion, and it shows the tension between the two worlds.

Asiadeh also faces cultural shock in a matter of what to consume in Vienna. During a party, she is being offered a glass of wine but she turns down the offer by saying, "I don't drink wine. My religion forbids it, you know. ..." (p. 116). Knowing that the people around him are eating pork, she immediately feels disgusted: But in her blood, her veins and nerves, was a dark ancient fear, a hate and disgust of the meat God had forbidden Muslims to eat (pp. 116-117). In Islamic teaching, Moslems are forbidden to eat pork, and this has been internalized deeply by Asiadeh, shown by the phrase 'in her blood, her veins and nerves'. Through this incident, it can be seen even small matters like food can be an important issue when it is related to someone's identity, in Asiadeh's case her as a Moslem.

In Chapter 18, Asiadeh is invited for dinner by prince Abdul Kerim and his assistant, Sam Dooth. Without having knowledge about the real identity of the prince, Asiadeh comes when knowing they are also from Turkey, just like her: It did not matter who the strangers were, as long as they were countrymen, clumps of earth from home (158). That quotation highlights how Asiah really misses Turkey. Due to this, everything about Turkey always makes her enthusiastic. Even though her current home is now in Vienna with Hassa, now her husband, she always feels that her real home is in Turkey.

As an individual, Asiadeh has multiple identities. Biologically, she is female. From religious point of view, she is a Moslem. After her marriage to Hassa, she acquired a new identity, as a wife. According to the cultural values she was raised with, Asiadeh thinks that as a wife she needs to serve Hassa well and stays loyal to him. However, her task as a wife is in clash with her identity as a part of Ottoman Empire. Abdul Kerim is the embodiment of Turkey, her home: The house on the Bosphorus, home, the blood-red sunsets of the Golden Horn, all that was reality again, embodied in the strange man who had narrow, evil lips and staring eyes (p. 163). Although the empire itself has collapsed, she believes that she still has to do her duty: to marry Prince Abdul Kerim.

In the end, Asiadeh chooses to commit her duty more as a Turkish than as a wife. The Western world, represented by Vienna, is a foreign world to her: All at once, she was afraid of this strange town, the foreign world into which she had been forced, a world that she did not understand, a world that bored her (p. 167). She cannot live like the people around her, including Hassa, because the cultural values she acquired are different from the Western values in Vienna. One of the examples is when she feels shocked to see how free the relationship between men and women in that city. As a girl being raised in a harem, it is not easy for Asiadeh to accept that kind of lifestyle. 
Even Asiadeh's love to Hassa cannot compete with her feeling of missing home: For Hassa was a good and beautiful man, but most certainly not a house (p. 223). Hassa is not a 'house' in which she can feel safe because the barriers between Eastern and Western world between them are too thick. Then she tries to find her own home back by choosing to be prince Abdul Kerim's wife. She leaves her identity as Hassa's wife and an Austrian and decides to be back to her root, as a part of the Ottoman Empire.

\section{Abdul Kerim and the Change of Identity}

The next character to be analyzed is Prince Abdul Kerim. After the fall of the empire, Abdul Kerim ran away to America. He decided to leave behind his past as a Turkish prince and start a new life. He even changed his name to John Rolland, a Western name. By changing his name, Abdul Kerim makes an effort to eliminate his old identity and to build a new one. The name changing also signifies the change of identity from an Easterner to a Westerner. This is how he positions himself in the new world.

However, no matter how he tries to leave behind his Eastern identity, from other people's perspective Abdul Kerim is still a Turkish. For instance, Sam Dooth still sees him as a prince: Behind the white stached skirt, behind the slim passport, there lived still the delicate soul of an Osman (p. 155). He might change his appearance and name, but other people still position him as someone from the Eastern world. This shows how identity is not only a matter of someone's subjectivity, but it also deals with positioning from other people.

Weeks mentioned that identity gives someone 'a sense of personal location, the stable core to your individuality' (dalam Giles \& Middleton, 1999, p. 50). The instability of identity leads to Rolland's identity crisis. His life as a scriptwriter in America is successful, and the films written by him are categorized as box-offices. Yet he never sees America as his home. Like Asiadeh, he always thinks west as the 'foreign world'. Ironically, he does not even know where his home is now because Turkey has experienced a major change from an empire to a republic. The lost 'home' causes conflicts inside Rolland's heart: He was a nomad, an exile, chasing after an unknown aim. His home? He did know anymore where his home was (p. 185). The word 'nomad' is used here to point out how Rolland or Abdul Kerim is in confusion to find his stable position in the world. Living in the Western world does not make him feel comfortable, and without him realizing it, it means that he cannot be separated from his Turkish identity.

Identity can demonstrate a form of power relation. In The Girl from The Golden Horn, Rolland's identity as a prince makes people respect him. Before Asiadeh knows that Rolland is prince Abdul Kerim, she is acting rude to the prince. In contrast, when Rolland reveals his identity, Asiadeh shows her respect. His higher position causes a dilemma in Asiadeh's heart to make a decision, to stay loyal to her husband or to obey the prince's command.

At first, Abdul Kerim wants to let go his prince identity. The purpose is to build a new life, but besides that, this identity also brings some bitter memories: Every touch with a fragment of the old world, every memory of the past brought on new pain, new tortures of helplessness and inescapable fate (p. 186). 'Old world' which refers to Turkey keeps haunting him, and the fall of the empire is the past that Abdul Kerim wants to forget. One of the ways to forget the bitter memories is, as already mentioned, to start a new life by having a new identity.

However, a letter from Asiadeh reminds Rolland of his past. The letter makes him remember that he is a Turkish prince. In the beginning, Rolland tells her to forget him since he has thrown away his identity as a royal prince, 
"Dear Asiadeh, I am not I anymore, and wish for your sake that you will not remain you forever. Our emperor and master has dreamt of both of us; that was in another incarnation. Your conscience can remain clear, for I do not exist anymore. Therefore you are completely free...” (p. 65).

This letter to Asiadeh shows his intention to abandon his previous identity, and he expects Asiadeh to do the same thing. Yet his meeting with Asiadeh's father in rug shop changes his intention. Even though they have been separated for years, Asiadeh's father still recognizes Rolland as a prince and still respects him as a member of the royal family.

Being reminded of his role as a prince, Abdul Kerim then goes straight to Vienna to meet Asiadeh. To him, Asiadeh is the way to find his lost 'home'. How he wants to have Asiadeh as his home can be seen when Asiadeh rejects his offer to go with him: "I don't need a woman," he said abruptly. "I don't need a home..." (178). It implies that in Abdul Kerim's mind, marrying Asiadeh means getting back his lost home, the place that offers stability and safety. When Asiadeh sends a telegram saying that she is willing to join him, Abdul Kerim finally says "[T]he home is offered to him by a woman.” (p. 218). In the end, he finds home in Asiadeh.

\section{CONCLUSION}

After being taken from their cultural roots, both Asiadeh and Abdul Kerim keep encountering problems about the meaning of home. For them, home is not just a matter of physical construction, but something that can make them feel stable and safe. The circumstance does not give a chance for them to go back to Turkey, so they struggle to find the meaning of home by building a new life with a new identity. Asiadeh goes to Austria as Hassa's wife, while Abdul Kerim flees to America and changes his name to John Rolland. However, Turkish cultural values internalized by them become obstacles for them to start a life in Western world. Neither Asiadeh nor Abdul Kerim can completely leave their Turkish identity.

At the end of the story, Asiadeh decides to follow Abdul Kerim. With him, she feels more like at home because they come from the same land, or in other words they share the same identity in form of blood and nationality. Asiadeh and Abdul Kerim then make a choice to build their new home in New York. This home is not totally new since they are still taking 'the ruins' from the old world, which is their identity as a part of the Ottoman Empire. By choosing Abdul Kerim, Asiadeh has taken her duty as a pasha's daughter, and Abdul Kerim is still commited to his role as a Turkish prince by marrying Asiadeh, the woman intended for him. Through these two characters, The Girl from The Golden Horn reveals the strong bond between identity and the meaning of home. The memories of Turkey remind Asiadeh and Abdul Kerim of their Turkish-ness. Yet in the end they realize that home is something that they build in their heart, so even though Ottoman Empire has fallen and Turkey has experienced a magnificent political change, their identity as a Turkish cannot be erased easily. 


\section{REFERENCES}

Baldwin, E., et al. (2004). Introducing cultural studies. Essex: Pearson Education.

Giles, J., \& Middleton, T. (1999). Studying culture: A practical introduction. Oxford: Blackwell.

Rutherford, J. (1990). Identity: Community, culture, difference. London: Lawrence and Wishart.

Said, K. (2001). The girl from the golden horn, trans. Jenia Graman. New York: Anchor Books. 